\title{
Integral assessment of heavy metal pollution in Don River estuary soils
}

\author{
Dina Nevidomskaya ${ }^{1},{ }^{*}$, Tatiana Minkina ${ }^{1}$, Yuri Fedorov ${ }^{1}$, Olga Nazarenko $^{2}$, Natalya \\ Kravtsova $^{1}$, and Yuri Litvinov ${ }^{1}$ \\ ${ }^{1}$ Southern Federal University, 344006 Rostov-on- Don, Russia \\ ${ }^{2}$ State Center for Agrochemical Service "Rostov", 346735 Rostov Region, Russia
}

\begin{abstract}
Based on the cumulative pollution index, spatial distribution maps were obtained to establish categories of soil pollution taking into account the total content of heavy metals and the mobile forms of metals in the Don River estuarine region. The objects of the study included samples of zonal soils (Chernozem) and intrazonal soils (Fluvisols) from monitoring plots. The total concentrations of $\mathrm{Mn}, \mathrm{Cr}, \mathrm{Ni}, \mathrm{Cu}, \mathrm{Zn}, \mathrm{Pb}$, and $\mathrm{Cd}$ in the soils were determined by $\mathrm{X}$-ray fluorescent scanning spectrometer. Mobile heavy metals compounds were transferred to a solution by extraction of $1 \mathrm{~N} \mathrm{NH}_{4} \mathrm{Ac}, \mathrm{pH} 4.8$. When calculating the total metal content, it was shown the studied soils had generally an acceptable pollution category but taking into account mobile forms the categories of soils contamination variate up acceptable to extremely dangerous. The most polluted sites are associated with the estuary of small rivers and the branches flowing into the Taganrog Bay, the territory of the Taganrog port and its terminals, and road bridges. In line with hight categories of pollution, the use of the soils for cropping should be limited, and the cultivation of concentrator plants is excluded.
\end{abstract}

\section{Introduction}

The territory of the Lower Don covers one of the most densely populated regions of the South of Russia, where associated with high-intensity economic activity in the catchments and water area, contributing to the flow of pollutants with a significant representation by heavy metal (HM) [1,2]. Of particular significance are the studies of the estuarine areas of large rivers, which are one of the most important links between land and sea. This area is considered a part of a marginal filter or a cascade of barrier zones with avalanche sedimentation, interpenetration, mixing and transformation of river and sea waters. This area is categorized by its differences from each other in the terms of salinity, ionic composition, HM and other substances of natural and anthropogenic origin $[3,4,5,6]$. Due to this fact, the development and application of indicators reflecting the actual ecological state of the soil cover are relevant [7].

\footnotetext{
*Corresponding author: dnevidomskaya@mail.ru
} 
The purpose of this work was to evaluate HM pollution of soil cover in the Don River estuary and obtain spatial distribution maps by the cumulative pollution index $(Z c)$ based on the results of long-term monitoring.

\section{Materials and methods}

The studies were conducted on the territory of the Don River estuary, which included a part of the river from the top of the delta - the Stanitsa of Razdorskaya to the confluence of the Taganrog Bay in the Sea of Azov [2]. Route and field studies were carried out in 20112019. At the monitoring sites, the soil was sampled from a depth of $0-20 \mathrm{~cm}$ according to the guidelines [8].

The major background of soil cover consists of low- and medium-humus Haplic Chernozem [9] of different depth on heavy loess-like loams or clays. Fluvisols [9] with different degrees of salinity occur in floodplains of small rivers and especially in the Don River delta [2].

According to the guidelines [10] the main physico-chemical attributes of soils were estimated: the total organic matter, particle size distribution, carbonates, exchangeable $\mathrm{Ca}^{2+}$ and $\mathrm{Mg}^{2+}, \mathrm{pH}$.

The total content of $\mathrm{Mn}, \mathrm{Cr}, \mathrm{Ni}, \mathrm{Cu}, \mathrm{Zn}, \mathrm{Pb}$, and $\mathrm{Cd}$ in soils was determined by $\mathrm{X}$-ray fluorescence method using a scanning spectrometer "SPECTROSCAN MAKC-GV". Mobile HM compounds were transferred to a solution by extraction of $1 \mathrm{~N}$ ammonium acetate buffer $\left(\mathrm{CH}_{3} \mathrm{COONH}_{4}\right)-\mathrm{AAB}$ at the following conditions: $\mathrm{pH} 4.8$, soil to solution ratio $1: 10$, extraction time 18 hours. Metal content in soil extracts was determined by atomic absorption spectrophotometry (AAS) using a BUCK Scientific 200 spectrophotometer.

The level of soil contamination with HMs was estimated by comparing with maximum permissible concentrations (MPCs) for total and mobile contents [11], and background contents [2].

The cumulative pollution index $(Z c)$ was calculated based on the equation represented in Eq. (1) [12]. This equation was used for the integral assessment of the level of HM pollution of soils (1) [12]:

$$
Z c=\Sigma K c-(n-1)
$$

where $K c$ is the concentration factor equal to the ratio of the actual total content of the element in the soil to its background value $(K c=C j / C b)$, and $\mathrm{n}$ is the number of chemical elements with $K c>1$. The HM pollution level of the study soils was compared with their background [2].

To assess the potential HM bioavailability for plants, it is proposed to modify the cumulative pollution index taking into account mobile forms of metals (2):

$$
K c=M j / M b
$$

where $M j$ is the actual content of mobile forms of HM in soil, and $M b$ is the content of mobile forms of HM in the soil which is taken as the background analogue of unpolluted soil [2].

\section{Results and discussion}

Comparison of the results of phisical and chemical analyses of Fluvisols from the examined monitoring plots demonstrates that the particle size distribution of soils is rather mixed and 
is re presented mainly by sandy, sandy loam, and clay-loam species. Fractions of fine and medium sand are predominant. The studied soils have a weakly alkaline or strongly alkaline reaction (7.3-8.9) and a low humus content of $0.2-3.7$, which was mainly determined by the qualitative content of the infused and redeposited material composing the inwashed and buried horizons. The high carbonate content from soil covers in some monitoring sites is associated with the presence of biogenic calcite in deposited horizons.

The excesses of total HMs content in soils over regulated MPCs have been established for $\mathrm{Zn}$ (up to 3 times), $\mathrm{Cr}$ (up to 2 times), $\mathrm{Pb}$ (up to 2 times), $\mathrm{Cu}$ (up to 1 times). It has been shown that the sources of $\mathrm{Zn}, \mathrm{Pb}, \mathrm{Cu}$ supply are of anthropogenic character due to excessive discharge of industrial and domestic wastewater, aerotechnogenic input. The high $\mathrm{Cr}$ level in soils is due to the natural lithogenic factor. Polyelement contamination is observed at the monitoring sites located on the sea edge of the Don River delta, in the estuarine zones of small rivers within the Azov Sea basin.

The content of HMs mobile forms in the soils has significantly exceeded MPCs, that of $\mathrm{Cd}$ (up to 10 times), $\mathrm{Zn}$ (more than 7 times), $\mathrm{Pb}$ (up to 2 times) and $\mathrm{Ni}$ (up to 4 times), which is a risk their high degree of bioavailability. The highest content of mobile forms is observed in sandy varieties of Fluvisols. This is related to the low contents of organic matter and fine fractions, which are the main carriers of metals.

With consideration of the total content of HM, the lowest $Z c$ is typical of light-textured low-humic monitoring sites located on the coast of the Taganrog Bay and the coastal part of the delta. The highest $Z c$ values are typical for Fluvisols with ups content of humus and clay particles facilitate HMs accumulation. Soils of almost all monitoring sites have allowable pollution categories $(Z c<16)$ (Fig. 1) [13].

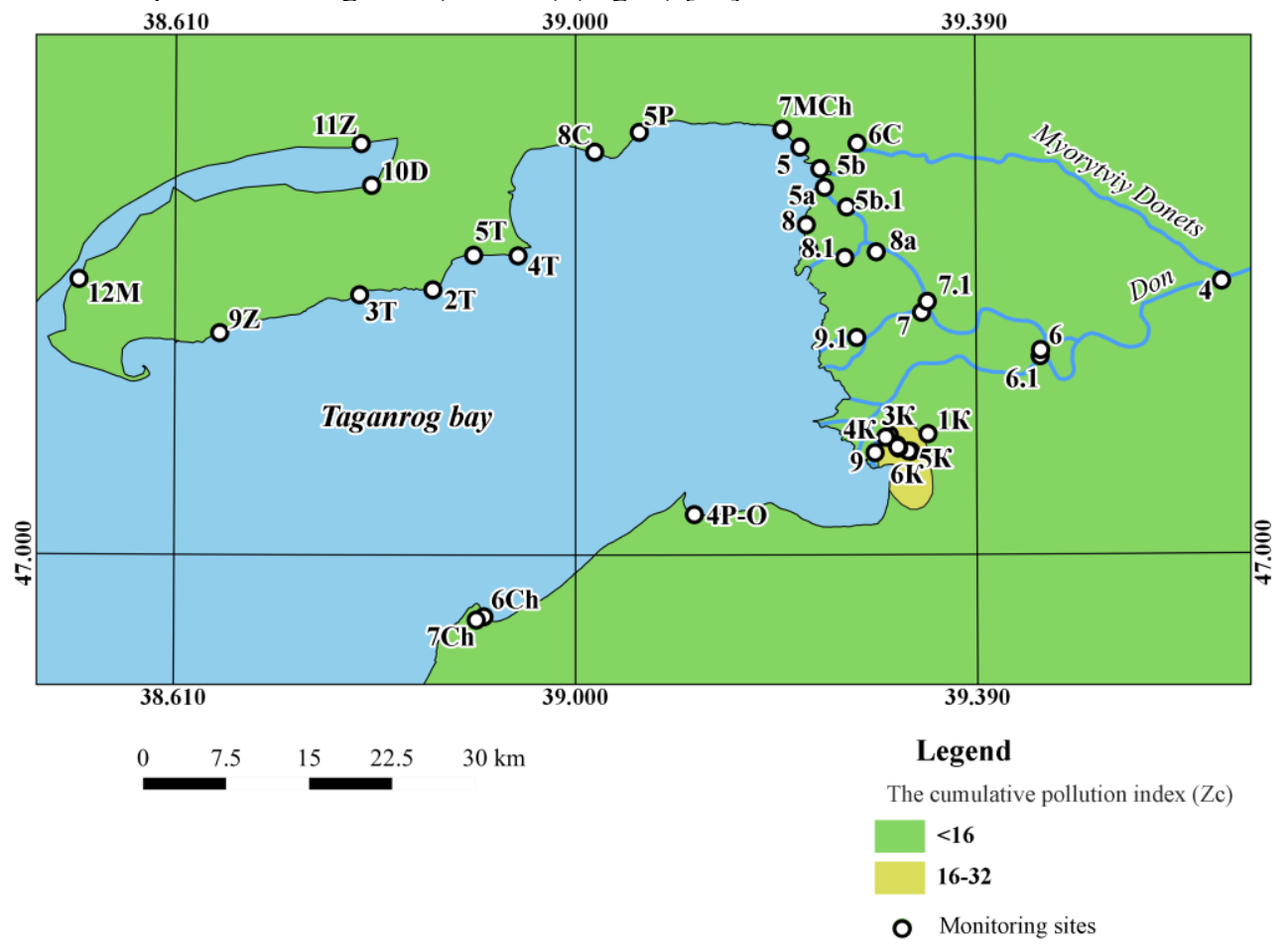

Fig. 1. Distribution map of the integral assessment of soil pollution $(Z c)$ taking into account the total content of HM. 
Taking into consideration the mobile forms of HM compounds, more significant differences were found in the values of $Z c$, which differed from the cumulative index calculated from the total contents (Fig. 2). Based on the calculation of $Z c$ for mobile forms, allowable soil pollution categories $(Z c<16)$ changed to dangerous $(Z c=32-128)$ and extremely dangerous $(Z c>128)$ ones. The pollution categories established by taking into account the mobile forms of $\mathrm{HM}$ compounds reasonably reflected the level of anthropogenic load on the soil cover. According to $Z c$, the most polluted monitoring sites are associated with the estuary of small rivers (Kagalnik, Sambek) and the branches flowing into the Taganrog Bay, the territory of the Taganrog port and its terminals, and road bridges. In line with these categories of pollution, the use of the soils for cropping should be limited, and the cultivation of concentrator plants is excluded.

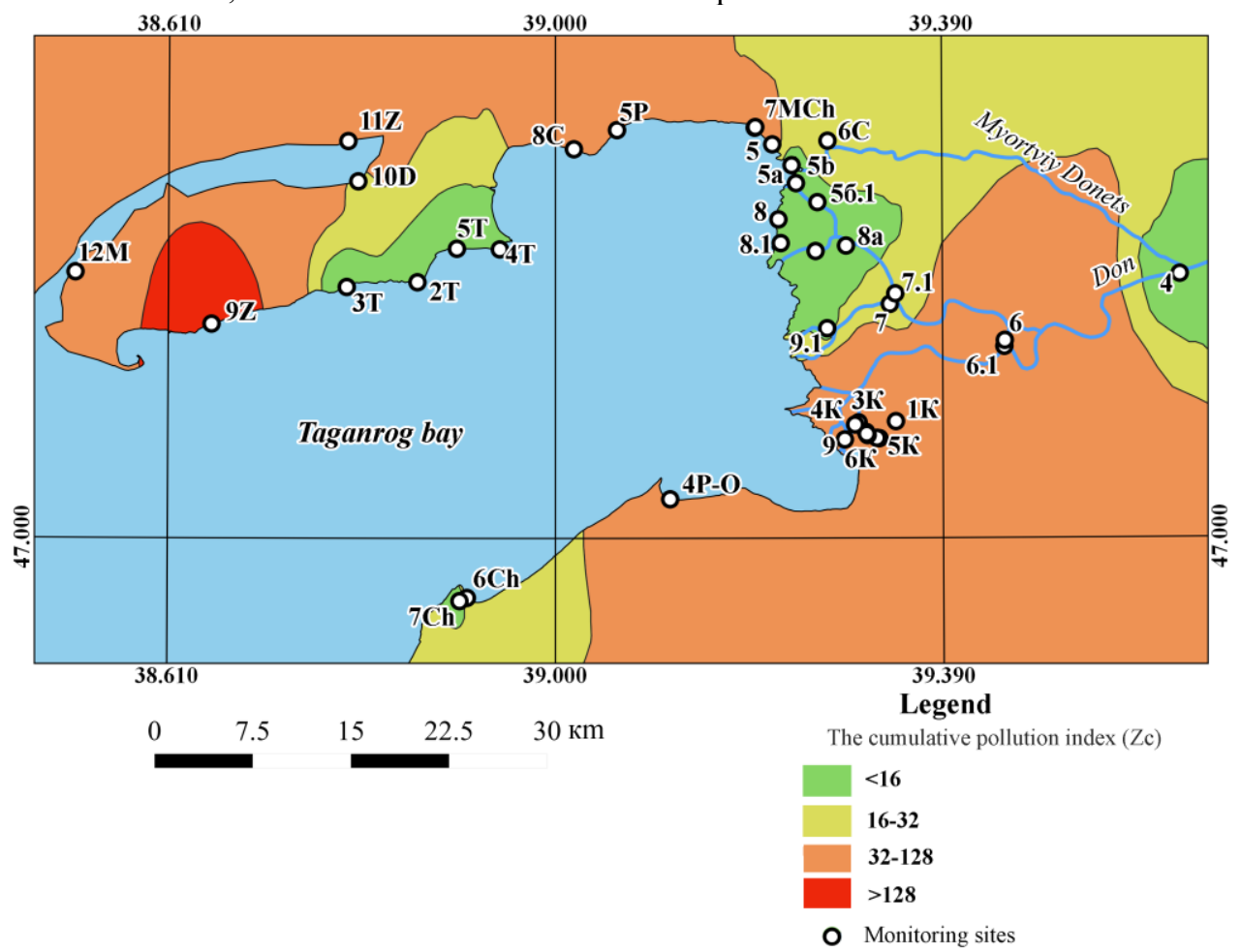

Fig. 2. Distribution map of the integral assessment of soil pollution $(Z c)$ taking into account the mobile forms of HM.

\section{Conclusions}

The use of the proposed cumulative soil pollution index $(Z c)$, by taking into account the mobile forms of HM made it possible to identify areas with different categories of pollution in the study area subject to anthropogenic impact. The most polluted sites are associated with the estuary of small rivers and the branches flowing into the Taganrog Bay, the territory of the Taganrog port and its terminals, and road bridges. In line with hight categories of pollution, the use of the soils for cropping should be limited, and the cultivation of concentrator plants is excluded. The risk of soil pollution is higher when buffer properties of soils are low. 
The research was financially supported by the project of the Ministry of Science and Higher Education of the Russian Federation within the framework of the state task (Southern Federal University), and the Russian Foundation for Basic Research, project no. 19-05-50097.

\section{References}

1. T. Minkina, Yu. Fedorov, D. Nevidomskaya, S. Mandzhieva, M. Kozlova, Arid. Ecosyst. 5, 4 (2015)

2. T. Minkina, D. Nevidomskaya, T. Pol'shina, Yu. Fedorov, S. Mandzhieva, V. Chaplygin, T. Bauer, M. Burachevskaya, J. Soils Sediments 17, 5 (2017)

3. G. C. Ray, J. McCormick-Ray, Estuarine ecosystems (Encyclopedea of Biodiversity Second Edition, 2013)

4. D. Romic, M. Romic, M. Zovko, H. Bakic, G. Ondrasek, Environ. Geochem. Health., 34 (2012).

5. A. Rovira, R. Ballinger, C. Ibáñez, P. Parker, M. D. Dominguez, X. Simon, A. Lewandowski, B. Hochfeld, M. Tudor, L. Vernaeve, J Soils Sediments, 14 (2014)

6. Yu. Fedorov, I. Dotsenko, A. Mikhailenko, SGEM, 1 (2015)

7. T. Minkina, G. Fedorenko, D. Nevidomskaya, T. Pol'shina, A. Fedorenko, V. Chaplygin, S. Mandzhieva, S. Sushkova, T. Hassan, Environ. Geochem. Health, (to be published) https://doi.org/10.1007/s10653-019-00379-3

8. GOST (State Standard) 58595-2019 Soils. General requirements for sampling. (Moscow, Rospotrebnadzor, 2019) (in Russian)

9. IUSS Working Group WRB. World reference base for soil resources 2014, update 2015. International soil classification system for naming soils and creating legends for soil maps. World soil resources reports, 106 (FAO, Rome, 2015)

10. L. Vorob'eva, Theory and practice chemical analysis of soils (Moscow, GEOS, 2006) (in Russian)

11. HS 2.1.7.2041-06. Maximum permissible concentrations of chemicals in soil: Hygienic standards. Introduction (Rospotrebnadzor, Moscow, 2006) (in Russian)

12. L. Håkanson, Water Resour., 14 (1980)

13. Guidelines MU 2.1.7.730-99 Hygienic evaluation of soil in residential areas (Rospotrebnadzor, Moscow, 1999) (in Russian) 